\title{
Synthesis of some new indeno[1,2-e]pyrazolo[5,1-c]-1,2,4-triazin-6-one and indeno[2,1-c]pyridazine-4-carbonitrile derivatives
}

\author{
Hamdi M. Hassaneen ${ }^{1^{*}}$, Nada M. Abunada ${ }^{2}$, Huwaida M. Hassaneen ${ }^{1}$ \\ ${ }^{1}$ Department of Chemistry, Faculty of Science, Cairo University, Cairo, Egypt; *Corresponding Author: Hamdihass@gmail.com \\ ${ }^{2}$ Department of Chemistry, Faculty of Applied Sciences, Al-Aqsa University, Gaza, Palestine
}

Received 5 October 2010; 8 November 2010; accepted 12 November 2010.

\begin{abstract}
Diazonium chlorides of 5-amino-3-methypyrazole $1 \mathrm{a}$ and 5-amino-4-phenylpyrazole $1 \mathrm{~b}$ coupled with 1,3-indanedione 2 and led to the formation of acyclic hydrazone $3 a$ and a cyclic product indenopyrazolotriazine $4 \mathrm{~b}$ respectively. Cyclization of the hydrazone $3 a$ by boiling in acetic acid afforded the corresponding $4 \mathrm{a}$. The hydrazone $3 a$ reacted with malononitrile in boiling ethanol in the presence of piperidine and gave indeno[2,1-c]pyridazine-4-carbonitrile derivatives $5 \mathrm{a}, \mathrm{b}$. Also, coupling of 6 with aryl diazonium chlorides gave the corresponding indenopyridazine derivatives 8a-e. Acetylation, benzoylation and hydrolysis of compound $8 \mathrm{a}$ afforded the corresponding substitution products 10-12, respectively. The structures of the newly synthesized compounds were established on the basis of chemical and spectral evidences.
\end{abstract}

Keywords: Diazonium Chlorides;

Indenopyrazolotriazine; Indenopyridazine

\section{INTRODUCTION}

As a part of our program aimed to developing synthesis of functionally substituted heteroaromatics from readily starting materials [1-5], we have previously reported the synthesis of 4,5-dihydrospiropyrazole-indane-1, 3-diones [6] and thiadiazoline derivatives [7] via reaction of hydrazonoyl halides with 2-arylidene indane-1, 3-dione and indane-1,3-dione-2-thiocarboxanilides, respectively. In conjunction of this work we intended here to utilize the known coupling reaction [8] of diazotized heterocyclic amines with active methylene compounds, using 1,3-indanedione as an active methylene compound with unreported heterocyclic amines to synthesize some new derivatives of the title compounds with anticipated biological activities. Our interest in synthesis of some novel indeno[1,2-e]pyrazolo[5,1-c]-1, 2,4-triazines, is owing to the fact that pyrazolo[5,1-c]-1, 2,4-triazines were reported to have remarkable cytotoxic activity against colon, breast and lung carcinoma cells [9], some derivatives show to have selective cytotoxicity in hypoxic and in normoxic conditions [10], hetarylazo derivatives were classified as diazo dyes [11]. Moreover, indeno-fused pyridazines have been reported to show inhibition potency toward monoamine oxidase-B (MAO-B) [12-14] and to display binding affinity for central benzodiazepine receptors [15].

\section{EXPERIMENTAL}

Melting points were measured on a Gallenkamp electrothermal melting point apparatus and are uncorrected. The infrared spectra were recorded in potassium bromide disks on a Pye Unicam SP 3-300 and Shimadzu FT-IR 8101 PC infrared spectrophotometer. The ${ }^{1} \mathrm{H}$ NMR $(200 \mathrm{MHz})$ and ${ }^{13} \mathrm{C}$ NMR $(50 \mathrm{MHz})$ spectra were recorded in DMSO-d $\mathrm{d}_{6}$ on a Varian Mercury VX 200 NMR using TMS as the internal reference. Mass spectra were measured on a GCMS-QP 1000 EX spectrometer at 70 $\mathrm{eV}$. Elemental analyses were carried out at the Microanalytical Centre of Cairo University, Giza, Egypt.

\subsection{Synthesis of 2-(3-Methylpyrazol-5-yl)Hydrazono-1, 3-Indanedione 3a}

To a stirred solution of $2(1.46 \mathrm{~g}, 10 \mathrm{mmol})$ in ethanol $(100 \mathrm{ml})$, sodium acetate trihydrate $(1.3 \mathrm{~g}, 10 \mathrm{mmol})$ was added. After stirring for $15 \mathrm{~min}$, the mixture was cooled to $0^{\circ} \mathrm{C}$ and treated with a cold solution of diazonium salt of aminopyrazole 1a [prepared from 3-methyl-5aminopyrazole $(0.97 \mathrm{~g}, 10 \mathrm{mmol})$ and appropriate quantity of hydrochloric acid and sodium nitrite]. The prod- 
uct separated on standing, was collected and crystallized from dimethylformamide to give $3 \mathrm{a}$ in $70 \%$ yield; $\mathrm{mp}$ $240^{\circ} \mathrm{C}$; IR $(\mathrm{KBr}) v_{\max } / \mathrm{cm}^{-1} 1654.6(\mathrm{C}=\mathrm{O}), 1716.5(\mathrm{C}=$ O), $3251.8(\mathrm{NH}), 3417.6(\mathrm{NH}) ;{ }^{1} \mathrm{H}$ NMR (DMSO-d 6 ) $\delta$ $2.31\left(\mathrm{~s}, 3 \mathrm{H}, \mathrm{CH}_{3}\right), 6.29(\mathrm{~s}, 1 \mathrm{H}$, pyrazole 4-CH), 7.818.19 (m, 4H, ArH's), 12.82 (s, 1H, NH), 13.45 (s, 1H, NH) ppm; ${ }^{13} \mathrm{C}$ NMR (DMSO-d 6 ) $\delta 167.9,153.7,145.9$, 135.6, 134.8, 130.9, 121.7, 93.8, 15.7; MS m/z $255\left(\mathrm{M}^{+}+\right.$ 1), $254\left(\mathrm{M}^{+}\right), 213,186,158,102,76,67$; Anal. Calcd. for $\mathrm{C}_{13} \mathrm{H}_{10} \mathrm{~N}_{4} \mathrm{O}_{2}: \mathrm{C}, 61.41 ; \mathrm{H}, 3.96 ; \mathrm{N}, 22.04$. Found: $\mathrm{C}$, 61.22; H, 3.79; N, 21.76\%.

\subsection{Synthesis of 2-Methyl-6H-Indeno[1,2-e]Pyrazolo [5,1-c]-1,2,4-Triazin-6-One 4a}

Compound $3 \mathrm{a}(1.27 \mathrm{~g}, 5 \mathrm{mmol})$ was refluxed in boiling acetic acid for $2 \mathrm{~h}$, excess solvent was evaporated under reduced pressure, and the residue was treated with methanol $(10 \mathrm{ml})$. The solid that formed was collected and crystallized from dimethylformamide to give $4 \mathrm{a}$ in $85 \%$ yield; $\operatorname{mp} 250^{\circ} \mathrm{C}$; IR $(\mathrm{KBr}) v_{\max } / \mathrm{cm}^{-1} 1728.2(\mathrm{C}=$ $\mathrm{O}) ;{ }^{1} \mathrm{H}$ NMR (DMSO-d $\left.{ }_{6}\right) \delta 2.71\left(\mathrm{~s}, 3 \mathrm{H}, \mathrm{CH}_{3}\right), 7.33(\mathrm{~s}$, 1H, pyrazole 4-CH), 7.71-8.19 (m, 4H, ArH's); ${ }^{13} \mathrm{C}$ NMR (DMSO-d $\left.{ }_{6}\right) \delta 184.5,153.6,151.4,147.2,145.8$, $139.9,134.3,132.6,128.8,127.3,123.6,96.8,14.9 ; \mathrm{MS}$ $\mathrm{m} / \mathrm{z} 237\left(\mathrm{M}^{+}+1\right), 236\left(\mathrm{M}^{+}\right), 195,168,143,139,114,88$, 53; Anal. Calcd. for $\mathrm{C}_{13} \mathrm{H}_{8} \mathrm{~N}_{4} \mathrm{O}: \mathrm{C}, 66.09 ; \mathrm{H}, 3.41 ; \mathrm{N}$, 23.72. Found: C, 65.87; H, 3.25; N, 23.54\%.

\subsection{Synthesis of 3-Phenyl-6H-Indeno[1,2-e]Pyrazolo [5,1-c]-1,2,4-Triazin-6-One 4b}

The compound was prepared by the same procedure described for the synthesis of compound $3 \mathrm{a}$ using 4-phenyl-3-aminopyrazole $1 \mathrm{~b}$ in place of $1 \mathrm{a}$. The compound crystallized from dimethylformamide to give $4 \mathrm{~b}$ in $70 \%$ yield; mp. $290^{\circ} \mathrm{C}$; IR $(\mathrm{KBr}) v_{\max } / \mathrm{cm}^{-1} 1726.6(\mathrm{C}=$ $\mathrm{O}) ;{ }^{1} \mathrm{H}$ NMR (DMSO-d $\left.{ }_{6}\right) \delta$ 7.32-8.43 (m, 9H, ArH's), $8.82(\mathrm{~s}, 1 \mathrm{H}$, pyrazole $2-\mathrm{CH}) ;{ }^{13} \mathrm{C}$ NMR $\left(\mathrm{DMSO}_{6}\right) \delta$ $184.6,148.2,147,3,139.9,136.2,135.7,132.4,130.7$, $129.7,129.2,126.8,124.7,123.6,123.3,121.6,97.5$; MS m/z $299\left(\mathrm{M}^{+}+1\right), 298\left(\mathrm{M}^{+}\right), 214,168,130,88,51$; Anal. Calcd. for $\mathrm{C}_{18} \mathrm{H}_{10} \mathrm{~N}_{4} \mathrm{O}: \mathrm{C}, 72.47 ; \mathrm{H}, 3.38 ; \mathrm{N}, 18.78$. Found: C, 72.22; H, 3.25; N, 18.49\%.

\subsection{Synthesis of 2-(Arylpyrazol-5-yl)- and 2-Aryl-3-Imino-9-(1,1-Dicyanomethylene)- 2-Hydroindeno[2,1-c]Pyridazine-4- carbonitrile $5 a, b$ and $8 a-e$}

Method A. To a solution of $3 \mathrm{a}$ or $7 \mathrm{a}-\mathrm{e}(5 \mathrm{mmol})$ and malononitrile $(6.6 \mathrm{~g}, 10 \mathrm{mmol})$ in absolute ethanol (40 ml) was added 3-4 drops of piperidine at room temperature. The reaction mixture was refluxed for $3 \mathrm{~h}$. The solvent was evaporated under reduced pressure and the residue was triturated with methanol $(10 \mathrm{ml})$ where it solidified. The crude product was collected and crystallized from dimethylformamide to give 5a and 8a-e respectively.

Method B. To a stirred solution of $6(2.24 \mathrm{~g}, 10 \mathrm{mmol})$ in ethanol $(100 \mathrm{ml})$, sodium acetate trihydrate $(1.3 \mathrm{~g}, 10$ mmol) was added. After stirring for 15 min the mixture was cooled to $0^{\circ} \mathrm{C}$ and treated with a cold solution of diazonium chloride of aminopyrazoles $1 \mathrm{a}, \mathrm{b}$ and aromatic amines 9a-e. The product separated on standing was collected by filtration and crystallized from dimethylformamide to give compounds $5 \mathrm{a}, \mathrm{b}$ and $8 \mathrm{a}-\mathrm{e}$ respectively.

9-(1,1-Dicyanomethylene)-3-imino-2-(3-methylpyrazo l-5-yl)-2,3-dihydro-9H-indeno[2,1-c]pyridazine-4-carbonitrile $5 a$, yield $85 \%$; mp $310^{\circ} \mathrm{C}$; IR (KBr) $v_{\max } / \mathrm{cm}^{-1}$ $2199.4(\mathrm{C} \equiv \mathrm{N}), 2225.6(\mathrm{C} \equiv \mathrm{N}), 2299.1(\mathrm{C} \equiv \mathrm{N}), 3201.9$ $(\mathrm{NH}), 3425.8(\mathrm{NH}) ;{ }^{1} \mathrm{H}$ NMR $\left(\mathrm{DMSO}_{-} \mathrm{d}_{6}\right) \delta 2.2(\mathrm{~s}, 3 \mathrm{H}$, $\left.\mathrm{CH}_{3}\right), 6.31$ (s, 1H, pyrazole 4-CH), 7.91-8.42 (m, 4H), $10.3(\mathrm{~s}, 1 \mathrm{H}, \mathrm{NH}), 12.91(\mathrm{~s}, 1 \mathrm{H}, \mathrm{NH}) ;{ }^{13} \mathrm{C}$ NMR $\left(\mathrm{DMSO}_{6}\right) \delta 154.9,153.6,150.7,149.7,136.8,136.1$, $134.9,132.4,131.2,129.5,126.6,126.3,111.4,110.6$, 98.5, 97.8, 80.6, 15.7; MS m/z $350\left(\mathrm{M}^{+}\right), 349,309,214$, 202, 152, 100, 67, 53; Anal. Calcd. for $\mathrm{C}_{19} \mathrm{H}_{10} \mathrm{~N}_{8}$ : C, 65.14; H, 2.88; N, 31.99. Found: C, 64.98; H, 2.65; N, $31.85 \%$.

9-(1,1-Dicyanomethylene)-3-imino-2-(4-phenylpyrazo l-5-yl)-2,3-dihydro-9H-indeno[2,1-c]pyridazine-4-carbonitrile $5 b$, yield $85 \%$; mp $322^{\circ} \mathrm{C}$; IR (KBr) $v_{\max } / \mathrm{cm}^{-1}$ $2197.2(\mathrm{C} \equiv \mathrm{N}), 2223.1(\mathrm{C} \equiv \mathrm{N}), 2299.3(\mathrm{C} \equiv \mathrm{N}), 3209.1$ (NH), $3429.3(\mathrm{NH}) ;{ }^{1} \mathrm{H}$ NMR $\left(\mathrm{DMSO}_{6}\right) \delta$ 7.73-8.42 (m, 10H, ArH's), 10.43 (s, 1H, NH), 12.90 (s, 1H, NH); ${ }^{13} \mathrm{C}$ NMR (DMSO-d 6 ) $\delta 155.1,153.8,151.5,149.6$, $136.7,136.0,134.5,132.6,131.4,131.1,129.3,129.1$, 128.4, 126.1, 126.5, 112.4, 111.6, 110.8, 98.8, 97.9, 80.0; MS m/z $413\left(\mathrm{M}^{+}+1\right), 412\left(\mathrm{M}^{+}\right), 387,348,329,214,202$, 152, 103, 64, 50; Anal. Calcd. for $\mathrm{C}_{24} \mathrm{H}_{12} \mathrm{~N}_{8}$ : C, 69.89; H, 2.93 ; N, 27.17. Found: C, 69.87; H, 2.93; N, 27.18\%.

2-(4-Chlorophenyl)-9-(1,1-dicyanomethylene)-3-imino2,3-dihydro-9H-indeno[2,1-c]pyridazine-4-carbonitrile $8 a$, yield $80 \%$; mp $310^{\circ} \mathrm{C}$; IR (KBr) $v_{\max } / \mathrm{cm}^{-1} 2144.5(\mathrm{C} \equiv$ $\mathrm{N}), 2225.3(\mathrm{C} \equiv \mathrm{N}), 2275.6(\mathrm{C} \equiv \mathrm{N}), 3301.3(\mathrm{NH}) ;{ }^{1} \mathrm{H}$ NMR (DMSO-d $)_{6} \delta$ 7.45-8.46 (m, 8H), $10.29(\mathrm{~s}, 1 \mathrm{H}$, $\mathrm{NH}) ; \mathrm{MS} \mathrm{m} / \mathrm{z} 383\left(\mathrm{M}^{+}+3\right), 382\left(\mathrm{M}^{+}+2\right), 381\left(\mathrm{M}^{+}+1\right)$, $380\left(\mathrm{M}^{+}\right), 379,334,290,214,159,111,75$; Anal. Calcd. for $\mathrm{C}_{21} \mathrm{H}_{9} \mathrm{ClN}_{6}: \mathrm{C}, 66.24 ; \mathrm{H}, 2.38 ; \mathrm{N}, 22.07$. Found: C, $66.98 ; \mathrm{H}, 2.38 ; \mathrm{N}, 22.08 \%$.

9-(1,1-Dicyanomethylene)-3-imino-2-(4-nitrophenyl)2,3-dihydro-9H-indeno[2,1-c]pyridazine-4-carbonitrile $8 b$, yield $77 \%$; mp $315^{\circ} \mathrm{C}$; IR (KBr) $v_{\max } / \mathrm{cm}^{-1} 2167.5(\mathrm{C} \equiv$ 
$\mathrm{N}), 2226.9(\mathrm{C} \equiv \mathrm{N}), 2250.6(\mathrm{C} \equiv \mathrm{N}), 3283.8(\mathrm{NH}) ;{ }^{1} \mathrm{H}$ NMR $\left(\right.$ DMSO-d $\left._{6}\right) \delta$ 7.51-8.46 $(\mathrm{m}, 8 \mathrm{H}), 10.28(\mathrm{~s}, 1 \mathrm{H}$, $\mathrm{NH}) ; \mathrm{MS} \mathrm{m} / \mathrm{z} 391\left(\mathrm{M}^{+}\right), 390,344,296,264,214,76$; Anal. Calcd. for $\mathrm{C}_{21} \mathrm{H}_{9} \mathrm{~N}_{7} \mathrm{O}_{2}: \mathrm{C}, 64.45 ; \mathrm{H}, 2.32 ; \mathrm{N}, 25.06$. Found: C, 64.38; H, 2.29; N, 24.94\%.

2-(4-Bromophenyl)-9-(1,1-dicyanomethylene)-3-imino2,3-dihydro-9H-indeno[2,1-c]pyridazine-4-carbonitrile $8 c$, yield $83 \%$; mp $280^{\circ} \mathrm{C}$; IR (KBr) $v_{\max } / \mathrm{cm}^{-1} 2167.4(\mathrm{C} \equiv$ $\mathrm{N}), 2227.1(\mathrm{C} \equiv \mathrm{N}), 2249.5(\mathrm{C} \equiv \mathrm{N}), 3311.2(\mathrm{NH}) ;{ }^{1} \mathrm{H}$ NMR (DMSO-d $)_{6} \delta$ 7.42-8.46 (m, 8H), $10.29(\mathrm{~s}, 1 \mathrm{H}$, $\mathrm{NH}) ; \mathrm{MS} \mathrm{m} / \mathrm{z} 427\left(\mathrm{M}^{+}+3\right), 425\left(\mathrm{M}^{+}+1\right), 377,376,296$, 268, 206, 178, 138, 90, 63; Anal. Calcd. for $\mathrm{C}_{21} \mathrm{H}_{9} \mathrm{BrN}_{6}$ : C, 59.30; H, 2.13; N, 19.76. Found: C, 59.24; H, 2.13; N, $19.72 \%$.

9-(1,1-Dicyanomethylene)-3-imino-2-(4-methylphenyl)2,3-dihydro-9H-indeno[2,1-c]pyridazine-4-carbonitrile $8 d$, yield $79 \%$; mp $290^{\circ} \mathrm{C}$; IR (KBr) $v_{\max } / \mathrm{cm}^{-1} 2188.9$ (C $\equiv$ $\mathrm{N}), 2222.9(\mathrm{C} \equiv \mathrm{N}), 2249.6(\mathrm{C} \equiv \mathrm{N}), 3286.3(\mathrm{NH}) ;{ }^{1} \mathrm{H}$ NMR (DMSO-d $)_{6} \delta 2.45\left(\mathrm{~s}, 3 \mathrm{H}, \mathrm{CH}_{3}\right), 7.45-8.49(\mathrm{~m}$, $8 \mathrm{H}), 10.31(\mathrm{~s}, 1 \mathrm{H}, \mathrm{NH}) ;{ }^{13} \mathrm{C}$ NMR $\left(\mathrm{DMSO}_{6}\right) \delta 154.8$, $153.6,149.9,137.1,136.9,136.1,135.2,134.5,132.3$, $131.7,131.1,126.6,126.2,116.8,111.4,109.4,98.4$, 80.9, 21.3; MS m/z $361\left(\mathrm{M}^{+}+1\right), 360\left(\mathrm{M}^{+}\right), 359,311$, 283, 214, 187, 149, 91, 65; Anal. Calcd. for $\mathrm{C}_{22} \mathrm{H}_{12} \mathrm{~N}_{6}$ : C, 73.32; H, 3.36; N, 23.32. Found: C, 73.02; H, 3.32; N, $23.15 \%$.

9-(1,1-Dicyanomethylene)-3-imino-2-(3-methylphenyl)2,3-dihydro-9H-indeno[2,1-c]pyridazine-4-carbonitrile $8 e$, yield $79 \%$; mp $275^{\circ} \mathrm{C}$; IR (KBr) $v_{\max } / \mathrm{cm}^{-1} 2182.6(\mathrm{C} \equiv$ $\mathrm{N}), 2223.4(\mathrm{C} \equiv \mathrm{N}), 2282.7(\mathrm{C} \equiv \mathrm{N}), 3276.2(\mathrm{NH}) ;{ }^{1} \mathrm{H}$ NMR $\left(\mathrm{DMSO}_{\mathrm{d}}\right) \delta 2.41\left(\mathrm{~s}, 3 \mathrm{H}, \mathrm{CH}_{3}\right), 7.47-8.49(\mathrm{~m}$, $8 \mathrm{H}), 10.30$ (s, 1H, NH); MS m/z $361\left(\mathrm{M}^{+}+1\right), 360\left(\mathrm{M}^{+}\right)$, 359, 313, 262, 213, 185, 129, 97, 55; Anal. Calcd. for $\mathrm{C}_{22} \mathrm{H}_{12} \mathrm{~N}_{6}$ : C, 73.32; H, 3.36; N, 23.32. Found: C, 73.29; H, 3.34; N, 23.31\%.

\subsection{Synthesis of 3-N-Acetylimino-2-(4-Chlorophenyl)- 9-(1,1-Dicyanomethylene)-2,3-Dihydro- 9H-Indeno[2,1-c]Pyridazine- 4-Carbonitrile 10}

A solution of $8 \mathrm{a}(1.9 \mathrm{~g}, 5 \mathrm{mmol})$ in acetic anhydride $(25 \mathrm{ml})$ was refluxed for $1 \mathrm{~h}$. The solvent was removed under reduced pressure and the residue was diluted with water. The solid formed was collected, washed with water and crystallized from dimethylformamide to give 9, yield $81 \%$, mp. $320^{\circ} \mathrm{C}$; IR $(\mathrm{KBr}) v_{\max } / \mathrm{cm}^{-1} 1674.5(\mathrm{C}=$ O), $2144.8(\mathrm{C} \equiv \mathrm{N}), 2224.4(\mathrm{C} \equiv \mathrm{N}), 2275.7(\mathrm{C} \equiv \mathrm{N}) ;{ }^{1} \mathrm{H}$ NMR (DMSO-d $)_{6} \delta 2.37\left(\mathrm{~s}, 3 \mathrm{H}, \mathrm{CH}_{3}\right), 7.47-8.49(\mathrm{~m}$, $8 \mathrm{H}) ; \mathrm{MS} \mathrm{m} / \mathrm{z} 425\left(\mathrm{M}^{+}+3\right), 424\left(\mathrm{M}^{+}+2\right), 423\left(\mathrm{M}^{+}+1\right)$, $422\left(\mathrm{M}^{+}\right), 409,407,383,382,381,380,379,344,295$, 214, 187, 111, 75; Anal Calcd. for $\mathrm{C}_{23} \mathrm{H}_{11} \mathrm{ClN}_{6} \mathrm{O}: \mathrm{C}$,
65.32; H, 2.62; N, 19.87. Found: C, 65.17; H, 2.45; N, $19.69 \%$.

\subsection{Synthesis of 3-N-Benzoylimino-2-(4-Chlorophenyl)- 9-(1,1-Dicyanomethylene)-2,3-Dihydro- 9H-Indeno[2,1-c]Pyridazine- 4-Carbonitrile 10}

A solution of $8 \mathrm{a}(1.9 \mathrm{~g}, 5 \mathrm{mmol})$ in pyridine $(30 \mathrm{ml})$ and benzoyl chloride $(0.58 \mathrm{ml}, 5 \mathrm{mmol})$ was reflux for $30 \mathrm{~min}$. The reaction mixture was left to cool, then treated with dilute hydrochloric acid $(50 \mathrm{ml})$. The crude product was collected and crystallized from dimethylformamide to give $\mathrm{N}$-benzoyl derivative 10 , yield $82 \%$, mp. $325^{\circ} \mathrm{C}$; IR $(\mathrm{KBr}) v_{\max } / \mathrm{cm}^{-1} 1674.8(\mathrm{C}=\mathrm{O}), 2144.4$ $(\mathrm{C} \equiv \mathrm{N}), 2224.9(\mathrm{C} \equiv \mathrm{N}), 2275.7(\mathrm{C} \equiv \mathrm{N}) ;) ;{ }^{1} \mathrm{H}$ NMR $\left(\mathrm{DMSO}_{-} \mathrm{d}_{6}\right) \delta$ 7.47-8.49 (m, 13H); MS m/z $487\left(\mathrm{M}^{+}+3\right)$, $486\left(\mathrm{M}^{+}+2\right), 485\left(\mathrm{M}^{+}+1\right), 484\left(\mathrm{M}^{+}\right), 411,383,382$, 381, 357, 105, 77, 51; Anal Calcd. for $\mathrm{C}_{28} \mathrm{H}_{13} \mathrm{ClN}_{6} \mathrm{O}: \mathrm{C}$, 69.35; H, 2.70; N, 17.33. Found: C, 69.28; H, 2.69; N, $17.35 \%$

\subsection{Synthesis of 2-(4-Chlorophenyl)- 9-(1,1-Dicyanomethylene)-3-Oxo- 2,3-Dihydro-9H-Indeno[2,1-c] Pyridazine-4-Carbonitrile 11}

Compound $8 \mathrm{a}(1.9 \mathrm{~g}, 5 \mathrm{mmol})$ was refluxed in dilute hydrochloric acid $(5 \mathrm{ml}, 10 \%)$ for $3 \mathrm{~h}$. The reaction mixture was cooled and the solid that precipitated was filtered, washed with water and crystallized from dimethylformamide to give 11 , yield $82 \%$, mp. $311^{\circ} \mathrm{C}$; IR $(\mathrm{KBr}) v_{\max } / \mathrm{cm}^{-1} 1675.3(\mathrm{C}=\mathrm{O}), 2144.9(\mathrm{C} \equiv \mathrm{N}), 2224.7$ $(\mathrm{C} \equiv \mathrm{N}), 2275.7(\mathrm{C} \equiv \mathrm{N}) ;{ }^{1} \mathrm{H}$ NMR $\left(\mathrm{DMSO}_{6}\right) \delta$ 7.45-8.47 (m, 8H); MS m/z $384\left(\mathrm{M}^{+}+3\right), 383\left(\mathrm{M}^{+}+2\right)$, $382\left(\mathrm{M}^{+}+1\right), 381\left(\mathrm{M}^{+}\right), 380,379,317,290,214,138$, 111, 75; Anal Calcd. for $\mathrm{C}_{21} \mathrm{H}_{8} \mathrm{ClN}_{5} \mathrm{O}: \mathrm{C}, 66.06 ; \mathrm{H}, 2.11$; N, 18.35. Found: C, 66.00; H, 2.09; N, 18.35\%.

\section{RESULTS AND DISCUSSION}

Coupling reaction of diazonium chloride of 5-amino3 -methypyrazole 1a with 1,3-indanedione 2 in the presence of sodium acetate led to the formation of one isolable product which analyzed correctly for $\mathrm{C}_{13} \mathrm{H}_{10} \mathrm{~N}_{4} \mathrm{O}_{2}$, although, the coupling reaction of pyrazole-3-diazonium chloride with 1,3-indanedione was reported to give a mixture of opened hydrazone and the cyclized product [16]. The structure of the resulting product was confirmed from its spectroscopic data to be the opened hydrazone 3 . IR spectrum revealed absorption bands at $v$ $3417.6,3251.8,1716.5$ and 1654.6 corresponding to the two $\mathrm{NH}$ and two $\mathrm{CO}$ groups, respectively. Its mass spec- 
trum showed an intense peak at $\mathrm{m} / \mathrm{z} 254$ assignable to molecular ion peak. The ${ }^{1} \mathrm{H}$ NMR spectrum of $3 \mathrm{a}$ exhibited singlet signal at $\delta 2.31 \mathrm{ppm}$ assignable to methyl protons, singlet signal at $\delta 6.29 \mathrm{ppm}$ for $4-\mathrm{H}$ pyrazole proton and characterized signals at $\delta 12.82$ and at $\delta$ $13.45 \mathrm{ppm}$ assignable to the two NH protons which disappeared in shaking with deuterium oxide. From the foregoing data the structure was proved to be 2-(3methyl-5-pyrazolyl)hydrazono-1,3-indanedione 3a. On refluxing in acetic acid compound 3 a cyclized through acid catalyzed nucleophilic addition elimination reaction to give 2-methylindeno[1,2-e]pyrazolo[5,1-c]- 1,2,4-triazin-6-one 4a (Scheme 1). The structure of $4 \mathrm{a}$ was confirmed on the basis of its elemental analysis and spectral data. ${ }^{1} \mathrm{H}$ NMR spectrum showed significant signals at $\delta$ 2.71, $7.33 \mathrm{ppm}$ assignable to methyl protons and $4-\mathrm{H}$ pyrazole proton respectively. The IR spectrum of $4 \mathrm{a}$ displayed only one carbonyl band at $v 1728.2 \mathrm{~cm}^{-1}$ and showed absence of the bands corresponding to the two NH groups in $3 \mathrm{a}$.

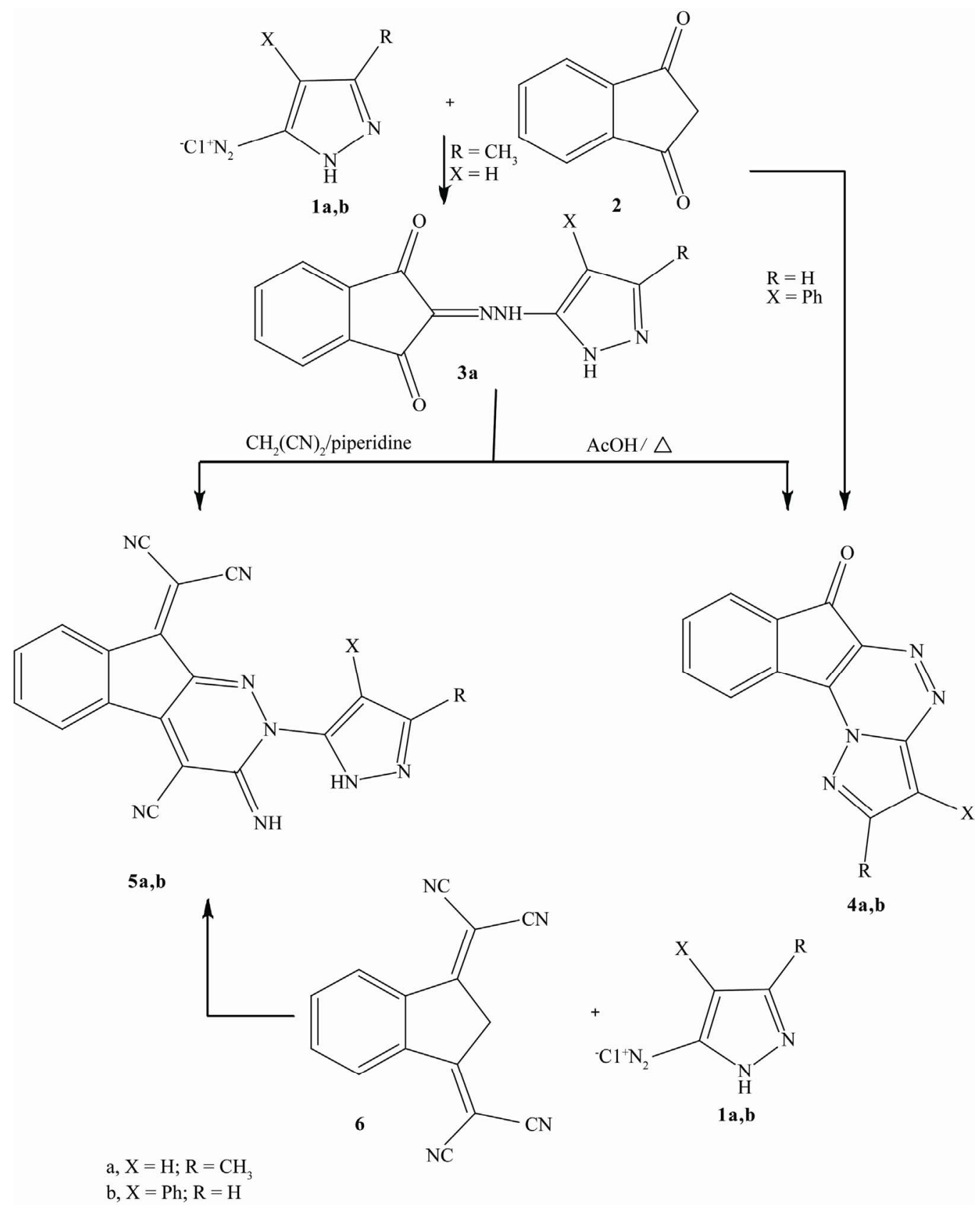

Scheme 1. synthesis of hydrazono-1,3-indanedione 3a, indeno[1,2-e]pyrazolo[5,1-c]triazin-6-one 4a,b and indeno[2,1-c]pyridazines 5a,b. 


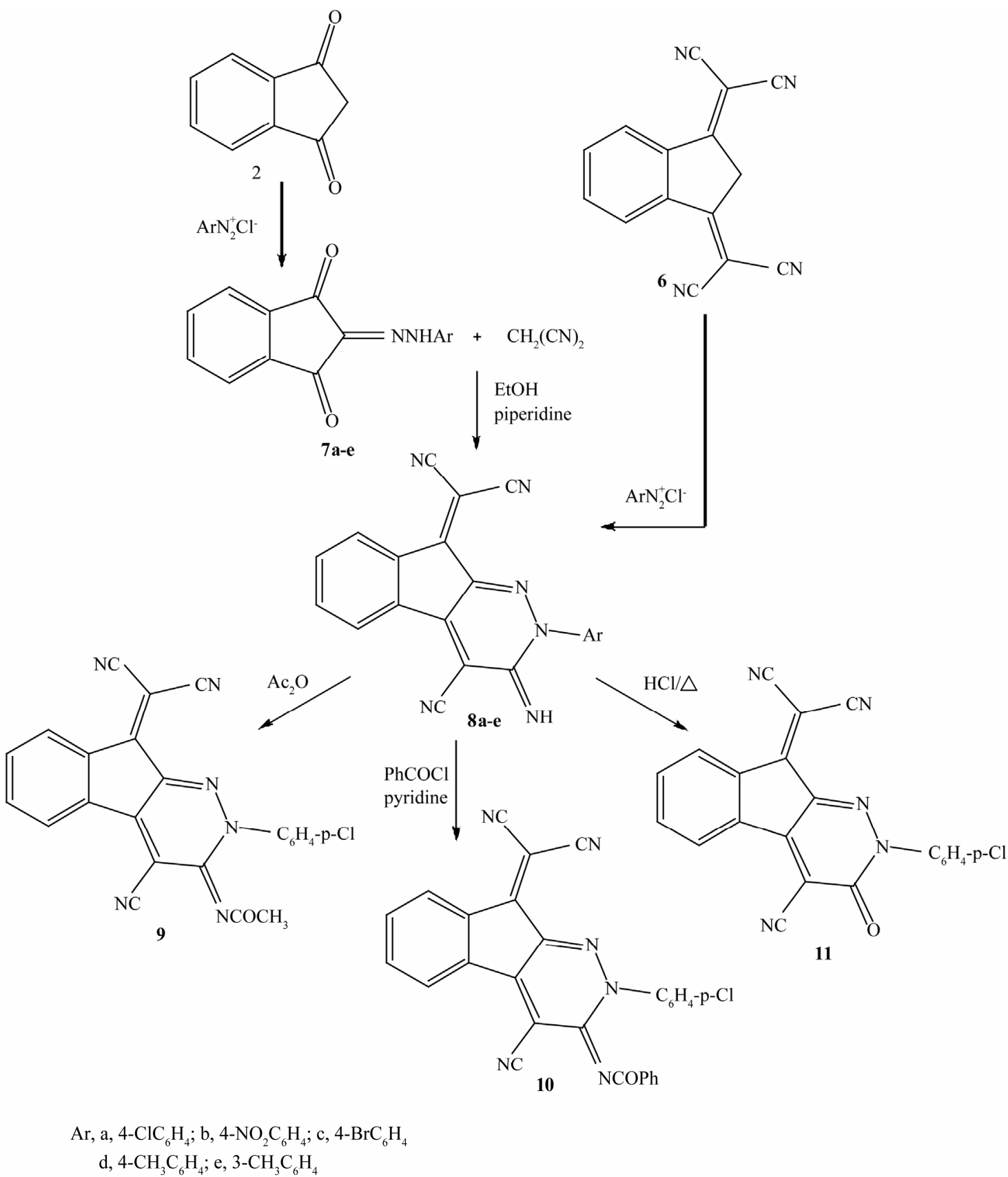

Scheme 2. Synthesis of iminoindeno[2,1-c]pyridazines 8 and its N-acetyl, N-benzoyl and oxo-derivatives 9-11.

Under similar conditions diazonium chloride of 5amino-4-phenylpyrazole $1 \mathrm{~b}$ coupled with 2 , but no hydrazone intermediate could be isolated, and instead the cyclized product $4 \mathrm{~b}$ was isolated. This is could be rationalize if we take into account the presence of more electron releasing phenyl group, compared with methyl one, increase the nucleophilicity of the pyrazole nitrogen to the extent it could complete the cyclization step to give the isolated product $4 \mathrm{~b}$. The structure of the new derivative $4 \mathrm{~b}$ was confirmed by its elemental and spec- tral analysis data [Experimental part].

Compound $3 \mathrm{a}$ reacted with malononitrile in boiling ethanol in the presence of piperidine and afforded the expected product 5a [17,18] (Scheme 1).The structure of the product was established on the basis of elemental and spectral analyses. The IR spectrum of 5 a revealed presence of three nitrile group bands at $v$ 2199.4, 2225.6 and $2299.1 \mathrm{~cm}^{-1}$, in addition to bands at $v 3201.9$ and $3425.8 \mathrm{~cm}^{-1}$ corresponding to imino $\mathrm{NH}$ in pyridazine [18] ring and $\mathrm{NH}$ of pyrazole ring, respectively. Its mass 
spectrum revealed the respective molecular ion peak at $\mathrm{m} / \mathrm{z}$ 350. Also, the ${ }^{1} \mathrm{H}$ NMR (DMSO- $\mathrm{d}_{6}$ ) spectrum of $5 \mathrm{a}$ showed characteristic signals at $\delta 2.26\left(\mathrm{~s}, 3 \mathrm{H}, \mathrm{CH}_{3}\right), 6.31$ (s, 1H, 4-CH pyrazole), in addition to two singlet signals at $\delta 10.32(1 \mathrm{H}, \mathrm{NH})$ and at $\delta 12.91(1 \mathrm{H}, \mathrm{NH})$, which disappeared by shaking with $\mathrm{D}_{2} \mathrm{O}$. Also, the structure of $5 \mathrm{a}$ was confirmed by its alternative synthesis by coupling of 1,3-bis-(dicyanomethylene)-2-hydroindene 6 [19], prepared from condensation of 1,3-indanedione with malononitrile, with diazonium salt of 3-methyl-5aminopyrazole 1a (Scheme 1). Similar treatment of 6 with diazotized 4-phenyl-5-aminopyrazole $1 \mathrm{~b}$ afforded the respective $5 \mathrm{~b}$; whose structure was proved on the basis of its correct analytical and spectral data (MS, IR, ${ }^{1} \mathrm{H}$ - and ${ }^{13} \mathrm{C}$-NMR).

Also, coupling of 6 with aryl diazonium chlorides 7a-e gave the corresponding [18] indeno[2,1-c]pyridazine $8 \mathrm{a}-\mathrm{e}$. The structures of the products $8 \mathrm{a}-\mathrm{e}$ were confirmed by their spectal (MS, IR, ${ }^{1} \mathrm{H}-$ and ${ }^{13} \mathrm{C}-\mathrm{NMR}$ ) and elemental analyses data (see Experimental). In the IR spectra of all products $8 \mathrm{a}-\mathrm{e}$, the characteristic nitrile absorption bands were at about $v$ 2144.5-2188.9, 2222.92227.1 and $2249.5-2282.7 \mathrm{~cm}^{-1}$ as well as imino $\mathrm{NH}$ absorption bands near $\vee 3276.3-3311.2 \mathrm{~cm}^{-1}$. The structures of $8 \mathrm{a}-\mathrm{e}$ were also confirmed by their alternative synthesis. Thus, reaction of $7 \mathrm{a}$-e $[20,21]$, prepared by coupling of 1,3-indanedione 2 with aryl diazonium chloride, with malononitrile in boiling ethanol in the presence of piperidine gave 8a-e (Scheme 2). Boiling compound $8 \mathrm{a}$ in acetic anhydride gave the corresponding $\mathrm{N}$-acetylimino derivative 9. Benzoylation of $8 \mathrm{a}$ with benzoyl chloride in pyridine afforded the corresponding $\mathrm{N}$-benzoylimino derivative 10 . Also, hydrolysis of $8 \mathrm{a}$ by refluxing in dilute hydrochloric acid gave the corresponding carbonyl derivative 11 (Scheme 2). The elemental analyses and spectral data (MS, IR, ${ }^{1} \mathrm{H}-$ and ${ }^{13} \mathrm{C}$-NMR) of the products 9-11 were all in agreement with the proposed structures [Experimental part].

\section{REFERENCES}

[1] Awad, E.M., Elwan, N.M., Hassaneen, H.M., Linden A. and Heimgartner H. (2001) Synthesis and reactivity of 2-(6,7-Diethoxy-3,4-dihydroisoquinolin-1-yl)acetonitrile towards hydrazonoyl halides. Helvetica Chimica Acta, 84, 1172-1180.

[2] Awad, E.M., Elwan, N.M., Hassaneen, H.M., Linden, A. and Heimgartner, H. (2002) New routes to fused isoquinolines. Helvetica Chimica Acta, 85, 320-332 .

[3] Abdallah, T.A., Darwish, M.A. and Hassaneen, H.M. (2002) A Novel Synthesis of 1,2,4-Triazolopteridines. Molecules, 7, 494-500.

[4] Hassaneen, H.M., Abdelhadi, H.A. and Abdallah, T.A. (2001) A novel synthesis of 1,2,4-triazolo[4,3-a]- pyrimidin5-one derivatives. Tetrahedron, 57, 10133- 10138.

[5] Abdallah, T.A., Abdelhadi, H.A., Hassaneen H.M. and
Hassaneen H.M. (2002) Michael reactions of arylidenesulfonylacetonitriles. A new route to polyfunctional Benzo[a] quinolizines. Molecules, 7, 540-548.

[6] Hassaneen, H.M., Elwan, N.M. and Hassaneen, H.M. (2002) Novel synthesis of 4,5-dihydrospiropyrazole-5, 2'-idane-1', 3'-diones. Synthetic Communications, 32, 3047-3055.

[7] Elwan, N.M., Hassaneen, H.M. and Hassaneen, H.M. (2002) Synthesis and reactions of indane-1, 3-dione2-thiocar-boxanilides with hydrazonoyl halides and active chloromethylene compounds. Heteroatom Chemistry, 13, 585-591.

[8] Kocevar, M., Stanovnik, B. and Tisler, M. (1978) 3-Diazopyrazolo[3,4-b]pyridine, a versatile synthon for new heterocyclic systems. Journal of Heterocyclic Chemistry, 15, 1175-1184.

[9] Cornnello, M., Ciciani, G., Mini, E., Guerrini, G., Caciagli, B., Selleri, S., Costanzo, A. and Mazzei T. (2005) Cytotoxic activity of 3-nitropyrazolo[5,1-c] [1,2,4]benzotri-azine derivatives: a new series of anti-proliferative agents. Anticancer Drugs, 16, 645-661.

[10] Ciciani, G., Coronnello, M., Guerrini, G., Selleri, S., Cantore, M., Failli, P., Mini, E. and Costanzo, A. (2008) Synthesis of new pyrazolo[5,1-c] $[1,2,4]$ benzotriazines, pyrazolo[5,1-c]pyrido[4,3-e][1,2,4] triazines and their open analogues as cytotoxic agents in normoxic and hypoxic conditions. Bioorganic \& Medicinal Chemistry, 16, 9409 -9419.

[11] Karci, F. and Karci, F. (2008) Synthesis of some novel pyrazolo[5,1-c]-1,2,4-triazine derivatives and investigation of their absorption spectra. Dyes pigment, 76, 97.

[12] Kneubuhier, S., Thull, U., Altomare, C., Carta, V., Gaillard, P., Carrupt, P.A., Carotti, A. and Testa, B. (1995), Inhibition of monoamine Oxidase-B by $5 \mathrm{H}$-Indeno [1,2-c] pyridazines: biological activities, quantitative structure-activity relationships (QSARs) and 3D-QSARs. Journal of Medicinal Chemistry, 38, 3874-3883.

[13] Altomare, C., Cellamare, S., Summo, L., Catto, M. and Carotti, A. (1998) Inhibition of monoamine Oxidase-B by condensed pyridazines and pyrimidines: Effects of lipophilicity and structure-activity relationships. Journal of Medicinal Chemistry, 41, 3812-3820.

[14] Carotti A., Catto M., Leonetti F., Campagna F., SotoOtero R., Mendez-Alvarez E., Thull U., Testa B. and Altomare C. (2007) Synthesis and monoamine oxidase inhibitory activity of new Pyridazine-, Pyrimidine- and 1,2,4-Triazine-Containing tricyclic derivatives. Journal of Medicinal Chemistry, 50, 5364-5371.

[15] Campagna F., Palluotto F., Mascla M. P., Maciocco E., Marra C., Carotti A. and Carrieri A. (2003) Synthesis and biological evaluation of pyridazino[4,3-b]indoles and indeno[1,2-c]pyridazines as new ligands of central and peripheral benzodiazepine receptors. II Farmaco, 58, 129140.

[16] Kocevar M., Kolman D., Krainc H., Polanc S., Porovne B., Stanovnik B. and Tisler M. (1976) Reactions of some diazoazoles with reactive methylene and other groups. Tetrahedron, 32, 725-729.

[17] Sofan M.A., El-Taweel F.M.and Elagamey A.G.A. (1990) Studies on 1,3-indandione: Synthesis of fluorenones and Indeno(2,1-c)pyridazine. Journal für Praktische Chemie, 332, 640-644. 
[18] Junek H., Klade M. and Sterk H. (1989) Über Dicyanmethylen-aminoindene, Indano-pyridazine und Indanopyridine. Synthesen mit Nitrilen, 83. Mitt. Monatshefte für Chemie, 120, 781-788.

[19] Gudriniece, E., Pastors, P. and Ievins, A. (1972) Condensaton of 1,3-indanedione with malononilrile. Doklady Akademii Nauk SSSR, 204, 874-875.
[20] Hocaoglu, N. and Uyar, T. (1987) Substituent and solvent effect on visible absorption spectra of 2-Substituted Phenylazo-1,3-indandiones. Journal of Spectroscopy, 8, 23-34.

[21] Hocaoglu, N., Uyar, T. and Turker, L. (1990) "The Synthesis of Some Novel 2-Substituted Phenylazo- 1,3- indandiones," Dyes Pigments, 12, 187-195. 